\title{
Efektivitas Permainan Bola Basket Modifikasi terhadap Kemampuan Motorik Kasar Anak Usia 5- 6 Tahun
}

\author{
Ardhana Reswari ${ }^{\boxplus}$ \\ Pendidikan Islam Anak Usia Dini, Institut Agama Islam Negeri Madura \\ DOI: $10.31004 /$ obsesi.v6i1.1182
}

\begin{abstract}
Abstrak
Strategi pembelajaran adalah hal yang penting dalam melaksanakan kegiatan belajar mengajar. Beberapa sekolah TK di daerah Ngajum Kabupaten Malang, mengalami permasalahan dalam hal pembelajaran fisik motorik. Kemampuan motorik kasar berkembang tidak sesuai dengan pertambahan usianya. Penelitian ini bertujuan untuk mengetahui efektivitas permainan bola basket modifikasi terhadap kemampuan motorik kasar anak usia 5-6 tahun. Jenis penelitian ini adalah Quasi Eksperimental dengan desain penelitian Nonequivalent Control Group Design. Penelitian ini dilakukan di RA Diponegoro dan TK AlHuda pada anak kelompok B. Pengambilan sampel dalam penelitian ini dilakukan secara acak (random sampling). Data yang diperoleh dikumpulkan dengan menggunakan metode observasi dan dokumentasi, kemudian dianalisis menggunakan analisis statistik dengan uji Anova. Hasil penelitian menunjukkan bahwa permainan bola basket modifikasi berpengaruh terhadap kemampuan motorik kasar anak usia 5-6 tahun. Berdasarkan hasil penelitian di atas, dapat disimpulkan bahwa efektivitas permainan bola basket modifikasi berpengaruh secara signifikan terhadap kemampuan motorik kasar anak usia 5-6 tahun.
\end{abstract}

Kata Kunci: permainan bola basket modifikasi; kemampuan motorik kasar; anak usia 5-6 tahun.

\begin{abstract}
Learning strategies are important in teaching and learning activities. Several kindergarten at Ngajum area Malang regency, have a problem in physical learning. The gross motor skills develop not according to age. The research aimed to find out about the effectiveness of basketball game modifications to the gross motor skills in children ages 5-6 years. This research used Quasi Experimental with Nonequivalent Control Group Design. The research was conducted in group B at RA Diponegoro and TK Al-Huda. Sampling in this research was carried out with randomly (random sampling). The research data are collected using observation and documentation technique and then analyzed using statistical analysis by Anova. The results showed that basketball game modifications have effect of gross motor skills in children aged 5-6 years. According the result, it can be concluded that the effectiveness basketball game modifications have significant effect of gross motor skills in children ages 5-6 years.
\end{abstract}

Keywords: basketball game modifications; the ability of gross motor skills; children aged 5-6 years.

Copyright (c) 2021 Ardhana Reswari

$\triangle$ Corresponding author :

Email Address : ardhana.reswari@iainmadura.ac.id (Madura, Indonesia)

Received 7 March 2021, Accepted 20 March 2021, Published 21 March 2021 


\section{PENDAHULUAN}

Usia 5-6 tahun merupakan usia keemasan (golden age) dalam proses perkembangan dan masa yang paling penting untuk pembentukan pengetahuan serta perilaku anak. Fase ini sangat berharga dan merupakan masa pembentukan, karena semua aspek perkembangan anak yang meliputi aspek kognitif, fisik motorik, bahasa, dan psikososial anak berkembang sangat pesat. Senada dengan hal tersebut, Santrock (2011) menegaskan bahwa pada masa usia dini anak mengalami masa kritis perkembangan yaitu saat dimana stimulasi spesifik dibutuhkan anak. Masa-masa keemasan ini tidak akan pernah terjadi dua kali, oleh karena itu pada masa ini lah, anak memperoleh stimulasi yang tepat. Tanpa adanya stimulasistimulasi yang diberikan kepada anak, sel-sel syaraf akan musnah melalui proses alamiah. Hal ini sesuai dengan prinsip kerja neuron otak, yaitu "you must use it or you can loose it".

Aspek perkembangan yang pesat pada anak usia 5-6 tahun adalah perkembangan fisik motoriknya. Hal tersebut juga diperkuat oleh Pang \& Fong (2010) yang mengemukakan bahwa kemampuan motorik kasar akan berkembang paling pesat pada fase anak memasuki usia prasekolah dan sekolah dasar. Menurut Gallahue dalam (Musfiroh, 2014) mengemukakan bahwa perkembangan fisik motorik adalah aspek perkembangan yang penting di awal kehidupan masa kanak-kanak. Proses tumbuh kembang motorik anak berhubungan dengan proses tumbuh kembang kemampuan gerak anak. Perkembangan fisik motorik anak akan terlihat jelas melalui berbagai aktivitas gerakan dan jenis-jenis permainan yang dilakukan oleh anak. Morrison (2012) menjelaskan bahwa kemampuan gerak berperan sangat penting dalam ekspetasi sosial dan kemampuan kognitif.

Perkembangan motorik terdiri dari dua kategori, yaitu motorik kasar dan motorik halus. Motorik kasar adalah aktivitas dengan menggunakan otot-otot besar yang meliputi gerak dasar lokomotor, non lokomotor, dan manipulatif seperti melempar, menangkap dan menendang. Sedangkan motorik halus adalah aktivitas yang menggunakan otot-otot kecil pada tangan dan otot pergelangan tangan, seperti menggunting, memotong dan menulis (Gallahue, 2012). Senada dengan hal tersebut, Fikriyati (2013) mengemukakan bahwa kemampuan motorik sangat berkaitan dengan perkembangan pengendalian gerakan tubuh, melalui kegiatan yang terkoordinir antara susunan syaraf, otot, otak dan spinal cord. Anak yang mampu menguasai gerakan kemampuan motorik kasarnya, maka kondisi tubuhnya akan semakin sehat karena anak selalu bergerak. Hal tersebut berpengaruh terhadap pada rasa percaya diri dan kemandirian yang ada pada diri anak. Anak lebih mudah bersosialisasi, karena mampu mengimbangi gerakan-gerakan dan aktivitas yang dilakukan bersama temanteman sebayanya.

Selaras dengan hal tersebut, Papalia (2014) mengemukakan bahwa anak yang mendapatkan kesempatan untuk berlatih dan diberikan stimulasi yang tepat serta sesuai dalam mengembangkan kemampuan motorik kasarnya, tentunya akan memiliki ketangkasan yang lebih baik dibanding dengan anak yang tidak mendapatkan kedua hal tersebut. Pada anak yang telah diberikan pembelajaran untuk menguasai gerakan tertentu, maka pada saat itu juga terjadi pembentukan koneksi antara stimulus dan respon. Koneksi yang terjadi tersebut, merupakan hasil dari proses latihan atau belajar yang dilakukan oleh anak.

Mobilitas yang tinggi merupakan ciri aktif anak usia 5-6 tahun yang ingin terus bergerak. Anak menyukai gerakan- gerakan sederhana seperti kemampuan dalam melompat, meloncat, melempar, menangkap, menendang dan berlari. Hal tersebut juga diperkuat oleh hasil penelitian Astutik \& Fitri (2019) yang mengemukakan bahwa hakikatnya anak usia dini sangat menyukai olahraga sederhana dan berbagai kegiatan fisik, anak tidak berdiri diam dan ingin terus bergerak. Namun kenyataannya di lapangan masih banyak anak yang mengalami permasalahan dalam perkembangan fisik motoriknya, khususnya motorik kasar yang berkembang tidak sesuai dengan pertambahan tingkat usianya. Tidak semua anak mendapatkan stimulasi yang tepat dan optimal dalam kebutuhan fisiknya dan hal ini berpengaruh pada perkembangan motorik kasar anak. 
Pada perkembangan motorik kasar anak usia 5-6 tahun, ada beberapa hal yang menjadi kendala secara keseluruhan, yaitu ketidakmampuan anak dalam mengatur keseimbangan tubuhnya, ketepatan anak dalam melempar dan menangkap sesuatu, serta kelincahan pada saat bergerak. Senada dengan hal tersebut, Wiyani (2014) menjelaskan bahwa sekitar $80 \%$ anak usia dini mengalami permasalahan pada ketidakseimbangan tubuh dan melakukan koordinasi gerak tubuh, sehingga anak kurang percaya diri dalam melakukan gerakan. Hal ini akan berdampak pada aktivitas sehari- hari anak yang dilakukannya, anak akan mengalami kesulitan dalam keseimbangan berjalan, menangkap atau melempar bola dengan tepat, kesulitan dalam mempertahankan postur tubuh saat berdiri, melompat, meloncat, berlari dan menggerakkan anggota tubuhnya yang lain.

Kemampuan motorik kasar yang perlu dikembangkan pada anak adalah kemampuan melompat. Anak harus menguasai gerakan ini dengan memiliki kemampuan koordinasi motorik, memiliki perencanaan dalam hal bergerak, dan keseimbangan yang baik dalam melakukan gerakan melompat tersebut. Pada perencanaan gerak, dibutuhkan kemampuan otak untuk melakukan perencanaan gerak dan kemudian dilaksanakan oleh motorik dalam bentuk gerak yang terkoordinasi. Suatu hal berbeda akan terjadi bagi anak yang memiliki kemampuan perencanaan gerak yang tidak berkembang dengan baik karena faktor kurangnya stimulasi. Hal tersebut akan mengakibatkan anak bermasalah dalam keseimbangannya. Anak akan lebih mudah lelah dan akan mempengaruhi konsentrasi.

Kemampuan lain yang juga perlu distimulasi pada kemampuan motorik kasar anak adalah kemampuan melempar. Mahmud (2019) menjelaskan bahwa faktor- faktor yang berperan penting dalam kemampuan melempar anak, yaitu 1) sensoris keseimbangan, 2) rasa sendi (propriosepsi), 3) visual. Peran yang paling utama dalam gerakan melempar ini adalah rasa sendi, yaitu kemampuan sendi merasakan suatu gerakan atau aktivitas. Misalnya, anak melakukan gerakan melempar bola, seberapa kuat dan lemah lemparannya agar bola tersebut masuk ke keranjang. Apabila gerakan melempar ini tidak mendapatkan latihan atau distimulasi dengan baik, maka anak akan mengalami masalah pada gerakan yang melibatkan gerak ekstremitas atas (bahu, lengan bawah, tangan dan jari-jarinya).

Kemampuan motorik kasar berkaitan erat dengan sistem syaraf yang ada di otak manusia. Otak terdiri dari belahan kanan dan kiri, kedua belahan otak ini harus selalu dalam keadaan keseimbangan. Senada dengan hal tersebut, Wiyani (2013) mengemukakan bahwa kegiatan berjalan dan berlari adalah aktivitas alami yang menggunakan pola bersilang dan berguna dalam menyeimbangkan belahan otak kanan serta kiri. Hal tersebut juga diperkuat oleh Aye et al. (2017) yang menyatakan bahwa kemampuan motorik kasar merupakan kemampuan yang ada pada diri anak yang harus dikembangkan, karena kemampuan ini memberikan pengaruh besar bagi kemampuan atau perkembangan anak lainnya, seperti kemampuan kognitif dan sosial emosional.

Salah satu strategi yang tepat untuk mestimulasi kemampuan motorik kasar anak yaitu bermain. Melalui bermain, anak belajar mengenali diri dan dunia di sekitarnya dengan eksplorasi dan meneliti berbagai hal yang dilihat, didengar dan dirasakannya. Mutiah (2012) juga menyatakan bahwa bermain sangat penting bagi anak usia dini pada kegiatan fisiknya karena memberikan kontribusi besar pada perkembangan kognitif, fisik, sosial dan emosional. Hasil penelitian dari The Smithsonian Institute, juga menjelaskan bahwa dalam PAUD pembelajaran paling efektif bila melalui pendekatan konkrit dan berorientasi pada bermain (Yus, 2011).

Namun, kenyataan di lapangan berdasarkan hasil observasi awal pada beberapa sekolah TK di daerah Ngajum Kabupaten Malang, kegiatan pembelajaran di TK, khususnya pada kemampuan motorik kasar sering sekali tidak memfasilitasi untuk bergerak dengan intensitas yang baik, sehingga anak kurang menguasai gerak dasar. Salah satu faktornya yang menyebabkan indikasi motorik kasar rendah, yaitu guru kurang memahami cara mengimplementasikan gerakan-gerakan fisik yang sesuai dengan tahapan perkembangan anak. Pembelajaran motorik kasar yang dilakukan belum memiliki formulasi yang jelas, mulai 
dari kegiatan pendahuluan sampai penutupan. Selain itu, faktor interen dari anak sendiri yang kurang berani atau percaya diri, keseimbangan, koordinasi gerak dan postur tubuh yang kurang benar dalam setiap melakukan gerakan. Selain itu, guru juga lebih memfokuskan pada peningkatan kemampuan kognitif anak, khususnya kemampuan calistung. Sehingga kondisi ini lah yang menyebabkan kurang terstimulasinya secara benar dan tepat untuk kemampuan motorik kasar anak. Beberapa data hasil observasi pun menunjukkan bahwa anak usia 5-6 tahun masih mengalami keterlambatan dalam kemampuan motorik dasar atau fundamental skills. Anak mengalami ketidakmampuan dalam mengontrol gerakan tubuh dengan baik, seperti melompat, meloncat, melempar dan menangkap bola dengan tepat, serta keseimbangan tubuh dalam berjalan dan berlari.

Permainan dapat memberikan kontribusi besar untuk perkembangan fisik motorik dan sosial emosioal anak (Theobald et al., 2015). Permainan yang banyak mengandung unsur gerakan tubuh, seperti berlari, melompat, melempar, menangkap dan memasukkan bola tepat sasaran, melatih konsentrasi atau berpikir anak serta dilakukan di luar ruangan, mengajak anak bersosialisasi dengan temannya adalah permainan bola basket yang dimodifikasi sesuai karakteristik anak usia 5-6 tahun. Hal tersebut juga diperkuat oleh Sitepu (2018) yang mengemukakan bahwa melalui permainan bola basket, anak akan bergerak lebih aktif, dapat meningkatkan dan mengoptimalkan kemampuan gerak-gerak dasar serta memberikan manfaat kesehatan bagi diri anak. Selain itu, bermain bola basket dapat memberikan pengalaman yang menyenangkan bagi anak.

Penelitian terdahulu yang relevan dengan penelitian ini dilakukan oleh Celik \& Johnson (2013) yang memberikan hasil penelitian bahwa kegiatan fisik seperti bermain basket, sepakbola, berlari akan memberikan manfaat pada kemampuan fisik motorik, sosial emosional dan perkembangan kognitif pada anak usia dini. Hal tersebut juga diperkuat oleh penelitian Gustiana (2011) terhadap anak TK kelompok B melalui permainan modifikasi basket dan sepak bola yang memberikan hasil cukup efektif dan memberikan kontribusi dalam meningkatkan keterampilan motorik kasar dan kognitif anak.

Permainan modifikasi merupakan salah satu inovasi pembelajaran pendidikan jasmani dalam hal motorik kasar yang disesuaikan dengan karakteristik perkembangan anak yang selalu ingin bergerak, susah untuk diam, mempunyai rasa ingin tahu yang kuat, senang bereksperimen, dan menguji, mampu mengekspresikan diri secara kreatif, mempunyai imajinasi, serta senang berbicara. Husdarta (2013) menjelaskan bahwa modifikasi adalah mengubah sesuatu dari keadaan lama menjadi keadaan yang baru tanpa mengubah karakter dasar sesuatu tersebut dengan memperhatikan kebutuhan yang akan dilakukan. Sejalan dengan hal tersebut Lesmana et al. (2016) juga mengemukakan bahwa untuk meningkatkan kemampuan motorik kasar pada anak dapat dilakukan melalui kegiatan melambungkan dan menangkap dengan berbagai media.

Pada penelitian ini, pemodifikasian permainan bola basket bertujuan untuk lebih meningkatkan kemampuan motorik kasar pada anak, khususnya memacu otot- otot besar anak, mengontrol gerakan tubuh, meningkatkan, mengembangkan dan mengkoordinasikan untuk kemampuan fisik motorik yang sehat, kuat, terampil dan lincah. Hal baru dalam penelitian ini yaitu peneliti akan lebih menekankan pada kegiatan bermain yang dirancang dengan kegiatan permainan yang menyenangkan dalam hal lempar tangkap bola (bounce and chess pass), dribble and shooting bola, dan bermain bola basket modifikasi dengan formasi 4 vs 4. Pemodifikasian pada permainan ini juga disesuaikan dengan aturan bermain, jumlah pemain, tinggi ring, ukuran bola, dan lapangan. Selain dapat meningkatkan motorik kasar pada anak, pemodifikasian permainan ini juga akan mengembangkan kecerdasan kinestetik, interpersonal, visual spasial dan logikal matematik yang belum ada pada hasil penelitian terdahulu.

Berdasarkan latar belakang di atas menggugah peneliti untuk menggunakan permainan bola basket modifikasi untuk meningkatkan kemampuan motorik kasar pada anak 
usia 5-6 tahun. Efektivitas dalam penggunaan permainan bola basket modifikasi ini dapat menarik perhatian dan memberikan kesan serta pembelajaran khusus terhadap anak.

\section{METODOLOGI}

Jenis penelitian ini menggunakan metode Quasi Eksperimen dengan tipe Nonequivalent Control Group Design. Waktu dan tempat penelitian ini dilakukan di RA Diponegoro dan TK Al-Huda pada anak usia 5-6 tahun kelompok B di Kecamatan Ngajum Kabupaten Malang Provinsi Jawa Timur. Penelitian ini dimulai pada bulan Februari- Maret 2020. Prosedur dalam penelitian ini adalah melakukan uji validitas dan uji realibilitas pada permainan bola basket modifikasi serta rencana pembelajarannya yang akan digunakan pada penelitian. Tahap- tahap penelitian diuraikan dalam bagan pada gambar 1 .

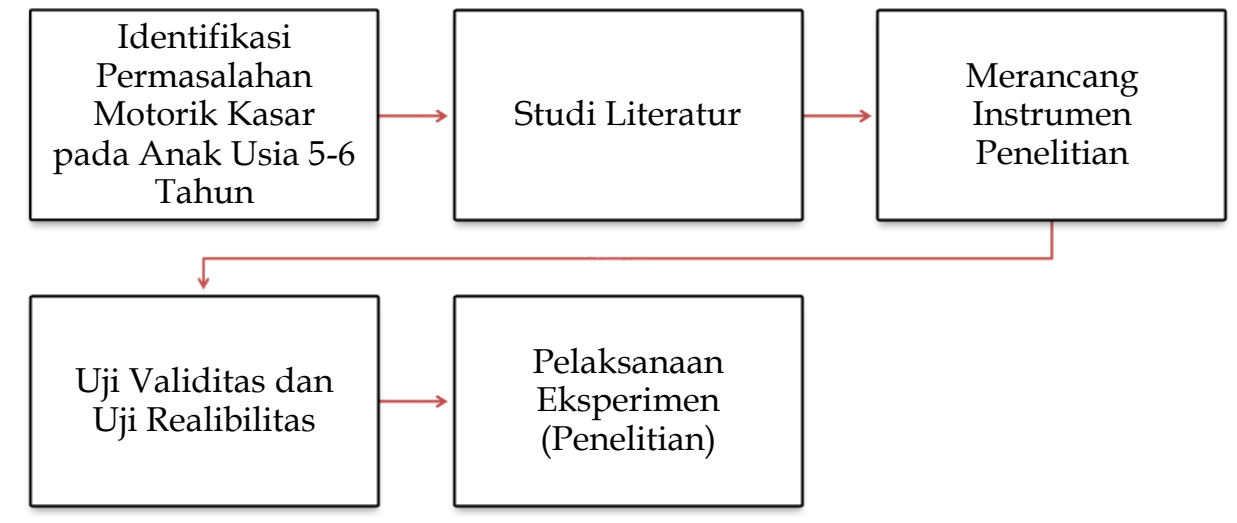

Gambar 1. Alur Penelitian

Pada gambar 1 merupakan ilustrasi tahap penelitian ini. Penelitian dimulai dari mengidentifikasi permasalahan motorik kasar pada anak usia 5-6 tahun yang dilakukan melalui observasi pada beberapa TK yang ada di Kecamatan Ngajum Kabupaten Malang. Tahap berikutnya, peneliti menelaah dan mengkaji literatur yang sesuai atau relevan dengan permasalahan pada penelitian ini. Kemudian merancang instrumen penelitian, media permainan dan membuat kisi- kisi sesuai indikator kemampuan motorik kasar pada anak usia 5-6 tahun. Langkah selanjutnya, melakukan uji validitas dan uji realibilitas instrumen, perangkat pembelajaran, media permainan bola basket modifikasi dan RPPH yang akan digunakan pada penelitian. Tahap terakhir adalah melakukan penelitian pada kelompok eksperimen dan kontrol.

Populasi dalam penelitian ini adalah anak kelompok B usia 5-6 tahun di TK Kecamatan Ngajum Kabupaten Malang. Populasi pada penelitian ini disajikan pada Tabel 1.

Tabel 1. Populasi Penelitian

\begin{tabular}{ccccc}
\hline \multirow{2}{*}{ No. } & \multirow{2}{*}{ Nama Lembaga } & \multicolumn{3}{c}{ Jumlah Anak } \\
& & L & P & Jumlah \\
\hline 1. & RA Diponegoro & 25 & 25 & 50 \\
2. & TK Bhayangkari & 14 & 16 & 30 \\
3. & TK Al Huda & 27 & 25 & 52 \\
4. & TK Darul Falah & 16 & 19 & 35 \\
5. & TK Dharma Wanita & 20 & 22 & 42 \\
\hline & Total & \multicolumn{4}{c}{$\mathbf{2 0 9}$} \\
\hline
\end{tabular}

Pengambilan sampel dalam penelitian ini dilakukan secara acak (random sampling). Pada prosedur sampling, peluang setiap anggota populasi memiliki peluang yang sama untuk terambil sebagai sampel. Berdasarkan teknik random sampling, maka penelitian ini menggunakan langkah-langkah sebagai berikut: 1) menulis nama- nama lima TK sebagai 
populasi pada kertas kecil, kemudian kertas di gulung dan dimasukkan ke dalam kotak lalu dikocok, 2) mengambil dua nama TK secara acak sebagai sampel untuk mendapatkan kelas eksperimen dan kelas kontrol, 3) Dua TK yang terpilih, diambil masing-masing dua kelompok untuk kelas eksperimen dan kelas kontrol. Adapun rincian dari sampel dalam penelitian ini disajikan pada Tabel 2 .

Tabel 2. Sampel Penelitian

\begin{tabular}{ccccc}
\hline No. & Nama TK & Kelas & Jumlah & Kelompok \\
\hline \multirow{2}{*}{ 1. } & \multirow{2}{*}{ RA Diponegoro } & B1 & 20 & Kontrol \\
& & B2 & 30 & Eksperimen \\
2. & \multirow{2}{*}{ TK Al Huda } & B1 & 22 & Kontrol \\
\cline { 2 - 5 } & J2 & 30 & Eksperimen \\
\cline { 2 - 3 } & \multicolumn{2}{c}{$\mathbf{1 0 2}$} & \\
\hline
\end{tabular}

Berdasarkan tabel 2, maka sampel yang dipilih berjumlah 102 anak yang terbagi menjadi 2 kelas, yaitu kelas eksperimen dan kelas kontrol. Kelas eksperimen dalam penelitian ini terdiri dari 2 kelas dengan jumlah sampel sebanyak 60 anak, sedangkan kelas kontrol terdiri dari 2 kelas juga dengan jumlah sampel sebanyak 42 anak.

Prosedur pada jenis penelitian Quasi Eksperimen dengan tipe Nonequivalent Control Group Design, dapat digambarkan dalam tabel 3.

Tabel 3. Desain Penelitian

\begin{tabular}{cccc}
\hline Kelompok & Pre-test & Perlakuan & Post-test \\
\hline Eksperimen & $\mathrm{O}_{1}$ & $X$ & $\mathrm{O}_{2}$ \\
Kontrol & $\mathrm{O}_{3}$ & - & $\mathrm{O}_{4}$ \\
\hline
\end{tabular}

(Sugiono, 2015)

Keterangan :

$\mathrm{O}_{1} \quad=$ nilai sebelum diberi perlakuan pada kelas eksperimen

$\mathrm{O}_{2} \quad=$ nilai kelas eksperimen setelah diperlakuan

$\mathrm{X}=$ penggunaan permainan bola basket modifikasi yang dikembangkan pada kelas eksperimen

$\mathrm{O}_{3} \quad=$ nilai sebelum diberi perlakuan pada kelas kontrol

$\mathrm{O}_{4} \quad=$ nilai sesudah diberi perlakuan pada kelas kontrol

- $\quad=$ kelas kontrol tidak diberi perlakuan

Peneliti melakukan teknik pengumpulan data dengan melihat perbedaan hasil observasi dari nilai sebelum dan sesudah perlakuan $\mathrm{O}_{1}$ dan $\mathrm{O}_{2}$ pada kelas eksperimen dengan $\mathrm{O}_{3}$ dan $\mathrm{O}_{4}$ pada kelas kontrol. Sehingga, melalui observasi dan dokumentasi dapat diketahui perbedaan antara $\mathrm{O}_{1}$ dan $\mathrm{O}_{2}$ pada kelas eksperimen dengan $\mathrm{O}_{3}$ dan $\mathrm{O}_{4}$ pada kelas kontrol.

Analisis data yang digunakan dalam penelitian ini adalah uji validitas yang dilakukan untuk mengukur apa yang seharusnya diukur. Data yang diperoleh kemudian dianalisis dengan menggunakan rumus Korelasi Product Moment melalui bantuan program SPSS 21 for windows. Sedangkan uji reliabilitas dengan menggunakan Alpha Cronbach (a), yang diperoleh dengan bantuan SPSS 21 windows evaluation version. Pengujian normalitas dilakukan dengan menggunakan program SPSS 21 for windows, yaitu dengan menggunakan rumus Kolmogorov Smirnov, dengan kriteria: Jika sig $\geq 0,05$ data berdistribusi normal. Uji F dikenal dengan Uji Anova, dalam penelitian ini digunakan untuk menguji bagaimanakah pengaruh permainan bola basket modifikasi terhadap kemampuan motorik kasar pada anak usia 5-6 tahun dengan ketentuan sebagai berikut: Jika $F_{\text {hitung }}<F_{\text {tabel }}$, maka $H_{0}$ diterima dan $H_{a}$ ditolak. Jika $F_{\text {hitung }}$ $>F_{\text {tabel }}$, maka $H_{0}$ ditolak dan $H_{a}$ diterima. 


\section{HASIL DAN PEMBAHASAN}

Pada penelitian ini, sebelum dilakukan uji hipotesis melalui metode statistika dengan formula Anova dengan satu jalur, hasil post test kemampuan motorik kasar terlebih dahulu harus memenuhi uji prasyarat. Adapun uji prasyarat yang dilakukan adalah uji normalitas dan uji homogenitas varians. Uji normalitas dilakukan untuk mengetahui apakah sebaran frekuensi data setiap variabel berdistribusi normal atau tidak. Pengujian normalitas dilakukan dengan menggunakan program SPSS 21,0 for Windows, yaitu dengan menggunakan rumus Kolmogorov Smirnov, dengan kriteria: jika sig $\geq 0,05$ maka data berdistribusi normal dan jika sig $<0,05$, maka data tidak berdistribusi normal. Adapun hasil perhitungan uji normalitas disajikan pada Tabel 4 dan Tabel 5.

Tabel 4. Uji Normalitas Kelompok Eksperimen

One-Sample Kolmogorov-Smirnov Test

\begin{tabular}{llrrrr}
\hline & & pre1 & pre2 & post1 & \multicolumn{2}{c}{ post2 } \\
$\mathrm{N}$ & & 60 & 60 & 60 & 60 \\
\hline Normal Parameters $^{\mathrm{a}}$ & Mean & 18.67 & 21.37 & 30.87 & 37.87 \\
& Std. Deviation & 3.754 & 5.008 & 2.332 & 3.094 \\
\multirow{2}{*}{ Most Extreme Difference } & Absolute & .154 & .133 & .112 & .110 \\
& Positive & .154 & .133 & .112 & .110 \\
& Negative & -.066 & -.085 & -.060 & -.061 \\
Kolmogorov-Smirnov Z & & 1.191 & 1.030 & .864 & .853 \\
Asymp. Sig. (2-tailed) & & .117 & .239 & .444 & .460 \\
\hline
\end{tabular}

Test distribution is Normal.

Tabel 5. Uji Normalitas Kelompok Kontrol

One-Sample Kolmogorov-Smirnov Test

\begin{tabular}{|c|c|c|c|c|c|}
\hline & & pre1 & pre2 & post1 & post2 \\
\hline \multicolumn{2}{|l|}{$\mathrm{N}$} & 42 & 42 & 42 & 42 \\
\hline \multirow[t]{2}{*}{ Normal Parametersa } & Mean & 19.81 & 20.00 & 22.26 & 23.12 \\
\hline & Std. Deviation & 2.662 & 3.379 & 2.119 & 3.202 \\
\hline \multirow[t]{3}{*}{ Most Extreme Differences } & Absolute & .091 & .122 & .129 & .079 \\
\hline & Positive & .091 & .122 & .129 & .079 \\
\hline & Negative & -.076 & -.071 & -.085 & -.061 \\
\hline Kolmogorov-Smirnov Z & & .587 & .789 & .836 & .514 \\
\hline Asymp. Sig. (2-tailed) & & .881 & .562 & .487 & .954 \\
\hline
\end{tabular}

Test distribution is Normal.

Berdasarkan hasil uji normalitas pada tabel 4 dan 5, dapat diketahui bahwa data tersebar normal untuk semua unit analisis, baik pada kelas eksperimen maupun kelas kontrol. Hal tersebut ditunjukkan pada nilai signifikansi pada uji statistik kolmogrof- smirnov yang menunjukkan nilai signifikansi lebih besar dari 0,05. Dapat dikatakan bahwa skor kemampuan motorik kasar anak usia 5-6 tahun pada kelas eksperimen dan kontrol berdistribusi normal.

Pengujian homogenitas dilakukan dengan uji Levene's Test yang dianalisis dengan program SPSS 21 for windows. Data dikatakan memiliki varian yang sama, jika angka signifikansinya lebih besar dari 0,05. Berikut pada tabel 6 disajikan hasil uji homogenitas varian data. 
Tabel 6. Uji Homogenitas Kemampuan Motorik Kasar

Test of Homogeneity of Variances

\begin{tabular}{rrrrr}
\hline Levene Statistic & df1 & & df2 & Sig. \\
\hline .037 & & 1 & 100 & .847 \\
\hline
\end{tabular}

Berdasarkan tabel 6 menunjukkan bahwa diperoleh hasil angka signifikansi sebesar 0,847 lebih besar dibandingkan 0,05. Hal tersebut menggambarkan bahwa kemampuan motorik kasar anak usia 5-6 tahun memiliki sebaran data yang homogen.

Tahap selanjutnya berdasarkan uji prasyarat, ditemukan bahwa data yang diperoleh berdistribusi normal dan memiliki varian data homogen. Kemudian melakukan pengujian hipotesis menggunakan Anova dengan bantuan program SPSS 21 for windows. Berikut data yang diperoleh pada tabel 7.

Tabel 7. Uji Anova Kemampuan Motorik Kasar

\begin{tabular}{lrrrrr}
\hline & Sum of Squares & \multicolumn{1}{c}{ Df } & Mean Square & F & Sig. \\
\hline Between Groups & 5373.338 & 1 & 5373.338 & 545.329 & .000 \\
Within Groups & 985.338 & 100 & 9.853 & & \\
Total & 6358.676 & 101 & & & \\
\hline
\end{tabular}

Berdasarkan tabel 7, diperoleh hasil uji One Way Anova untuk uji hipotesis yaitu nilai $F_{\text {hitung }}$ sebesar 545,329 dan nilai signifikansi sebesar 0,000. Sedangkan nilai $F_{\text {tabel }}$ 3,16 dengan taraf $5 \%$ atau 0,05 . $F_{\text {hitung }}$ lebih besar dari pada $F_{\text {tabel }}$, yaitu 545,329 $>3,16$. Sehingga, $H_{0}$ ditolak dan $H_{a}$ diterima, yang artinya bahwa efektivitas permainan bola basket modifikasi berpengaruh terhadap kemampuan motorik kasar pada anak usia 5-6 tahun di Kecamatan Ngajum Kabupaten Malang.

Grafik 1 adalah hasil perbandingan rerata skor perolehan bintang pada kemampuan motorik kasar anak di kelas eksperimen dan kelas kontrol.

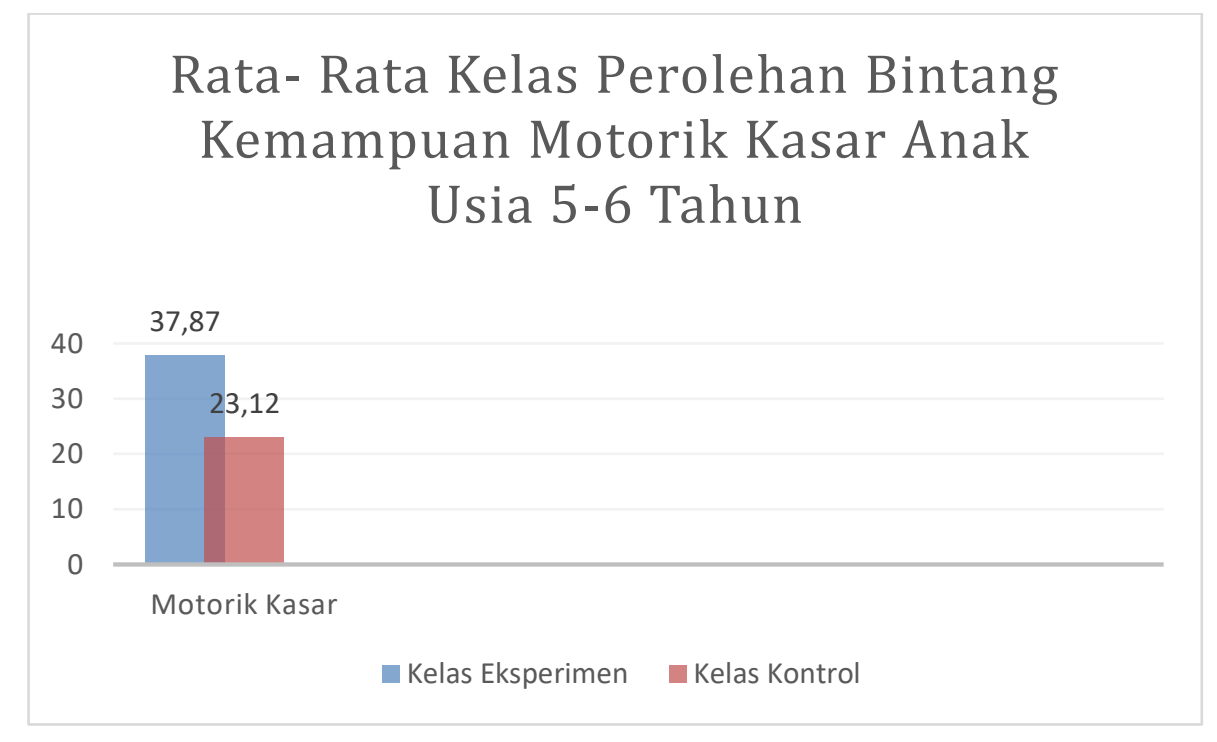

\section{Grafik 1. Rata- rata Kelas Perolehan Bintang Kemampuan Motorik Kasar Anak Usia 5-6 Tahun}

Temuan empiris berdasarkan grafik 1 menunjukkan bahwa anak yang berada pada kelas eksperimen dengan mendapatkan perlakuan berupa permainan bola basket modifikasi, berada pada kualifikasi berkembang sangat baik dan meningkat kemampuan motorik kasarnya dibandingkan pada kelas kontrol. Hal tersebut dapat disimpulkan bahwa 
kemampuan motorik kasar anak pada kelompok eksperimen sebesar 37,87 lebih besar dari pada anak pada kelompok kontrol yang memiliki rata-rata nilai 23,12.

Pelaksanaan pada penelitian ini menggunakan permainan bola basket modifikasi yang dirancang untuk mengembangkan kemampuan motorik kasar anak sesuai dengan tahapan dan karakteristik anak usia 5-6 tahun TK Kelompok B. Kegiatan fisik terpadu akan membantu anak terlibat secara bersamaan antara otak dengan tubuh anak dalam belajar. Hal tersebut sesuai dengan penyataan Zirawaga, V., Olusanya, A., \& Maduki (2017) yang menjelaskan bahwa melalui permainan- permainan yang telah dimodifikasi sesuai dengan kebutuhan dan karakteristik anak akan membantu daya ingat anak, keterampilan memecahkan masalah, melatih daya fokus anak dan mengajarkan anak untuk mentaati suatu aturan.

Sejalan dengan pernyataan tersebut, Marshall (2017) mengemukakan bahwa pemberian kegiatan fisik dengan aktivitas bermain akan melatih koordinasi mata dan tangan. Perkembangan motorik pada anak adalah perubahan yang berkaitan dengan kematangan mekanisme otot syaraf yang memberikan penampilan progresif di dalam keterampilan motorik. Hasil penelitian juga mendukung pendapat beberapa ahli terkait dengan pentingnya motorik kasar yang dilakukan melalui permainan, yaitu Vameghi, R., Shams, A., \& Dehkordi (2013) yang menjelaskan bahwa pengembangan program keterampilan gerak dasar pada anak sebaiknya dilakukan pada periode kritisnya usia 3-6 tahun dan keterampilan gerak dasar anak tergantung pada pengalaman dan berbagai permainan yang terprogram serta terorganisasi dengan baik.

Hal tersebut juga sejalan dengan penelitian Rizkiyah, Hendrawijaya \& Himmah (2018) yang menjelaskan bahwa untuk mengoptimalkan kemampuan motorik kasar pada anak diperlukan suatu pemberian latihan yang terpadu yang disesuaikan dengan karakteristik anak usia dini. Pada pelaksanaan penelitian ini, ditemukan data bahwa anak yang mengikuti treatment permainan bola basket modifikasi memiliki kemampuan motorik kasar yang lebih baik dari pada anak yang tidak mengikuti treatment permainan bola basket modifikasi. Temuan tersebut juga diperkuat oleh penelitian dari Pradaya et al. (2020) yang mengemukakan bahwa kemampuan motorik kasar dapat ditingkatkan dengan permainanpermainan olahraga, salah satunya yaitu dengan bermain bola basket yang telah dimodifikasi.

Teori- teori tersebut juga didukung oleh Breslin (2012) yang menyatakan bahwa pemberian stimulasi gerak dasar atau fundamental skill untuk anak dengan program- program yang sesuai dengan tingkat karakteristik anak secara terencana dan terprogram akan mampu meningkatkan kemampuan motorik kasar anak, diantaranya gerak dasar dalam menangkap, melempar bola, melompat dengan dua kaki dan berdiri melalukan keseimbangan dengan satu kaki. Hal tersebut juga sejalan dengan penelitian Ramdani \& Azizah (2019) yang menyatakan bahwa permainan-permainan fisik efektif untuk dilaksanakan di TK, karena dapat meningkatkan kemampuan motorik anak.

Pentingnya pembuatan program yang terencana dan terstruktur dalam pengembangan keterampilan motorik kasar ditekankan oleh Payne, V. Gregory \& Isaacs (2012) yang menyatakan bahwa "the children don't acquire for these skills as result of the maturation process, but the children rather through instruction and practise". Oleh karena itu diperlukan suatu pembelajaran gerak anak yang mampu memfasilitasi dan menstimulasi keterampilan gerak dasar anak serta mampu memberikan kesenangan, partisipasi dan kepuasaan bagi anak.

Dampak positif dari efektivitas permainan bola basket modifikasi, kemampuan motorik kasar anak akan meningkat dan berkembang, karena dalam permainan ini menggunakan teknik melempar, menangkap, berjalan, berlari, dan melompat yang merupakan gerak dasar anak. Gerakan motorik kasar adalah kemampuan yang membutuhkan koordinasi sebagian besar bagian tubuh anak. Permainan bola basket merupakan permainan yang memacu anak untuk bergerak teratur, semua otot-otot bergerak, organ-organ tubuh bekerja dengan baik sesuai dengan fungsinya. Kemampuan gerak dasar anak akan distimulasi secara optimal melalui permainan bola basket modifikasi. Kemampuan gerak dasar tersebut, antara lain melempar bola dengan lemparan dada (chest pass), melempar 
bola dengan lemparan pantulan (bounce pass), menangkap bola yang lurus dan melambung atau dipantulkan, mendribble bola basket angka, memasukkan bola basket ke ring dengan dua tangan dan berlari sambil melompat. Gerakan-gerakan dasar tersebut sangat penting bagi aktivitas sehari-hari anak, membuat anak aktif bergerak, dan anak dapat berinteraksi dengan teman-temannya selama permainan berlangsung. Bermain basket untuk anak TK akan difokuskan pada belajar bermain yang menyenangkan bukan pada kompetisi.

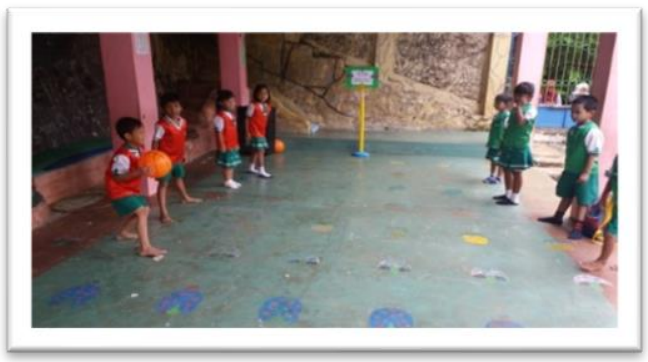

Gambar 2. Anak melakukan lemparan dada (chest pass) dan menangkap bola

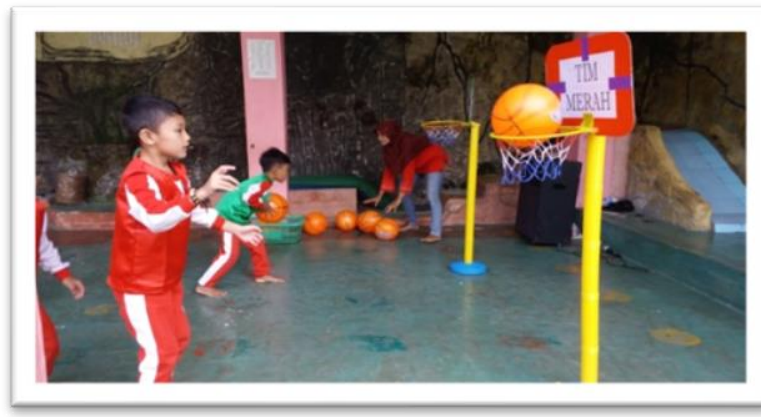

Gambar 4. Anak memasukkan bola basket ke ring, kemudian menghitung jumlah bola yang berhasil dimasukkan

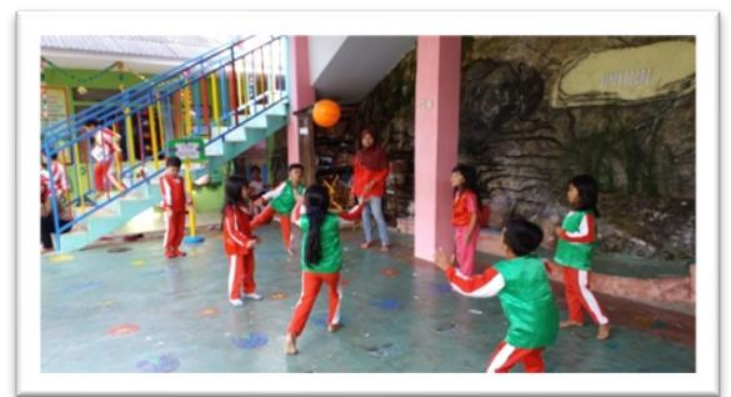

Gambar 6. Anak melakukan permainan bola basket modifikasi formasi 4 vs 4

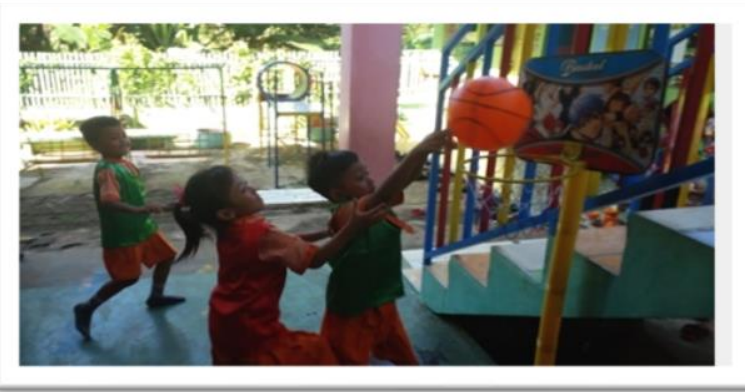

Gambar 8. Anak berhasil memasukkan bola basket ke ring lawan

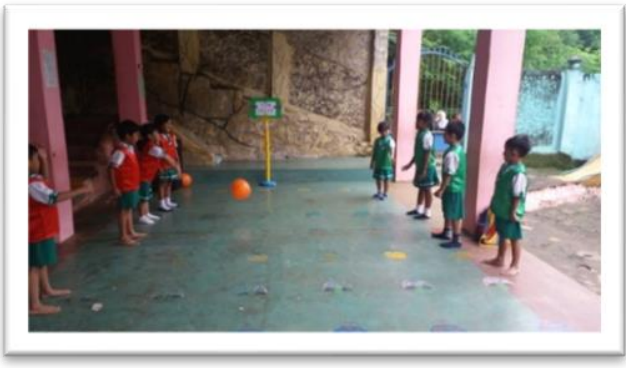

Gambar 3. Anak melakukan lemparan pantulan (bounce pass)

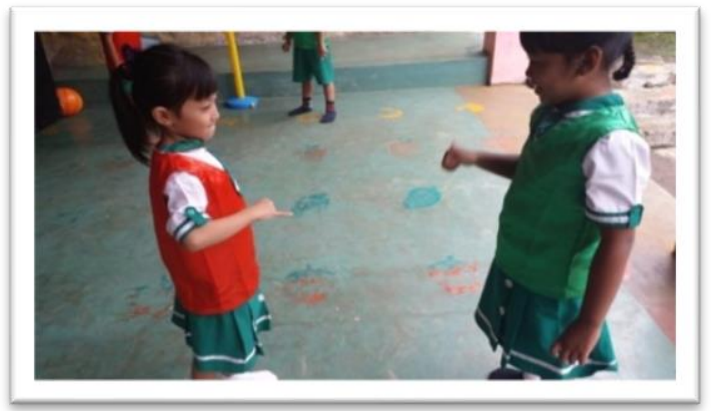

Gambar 5. Anak melakukan suit untuk menentukan tim mana yang mendapatkan bola terlebih dahulu

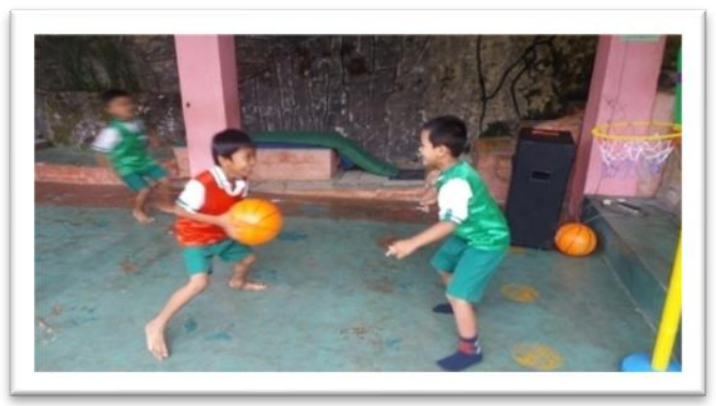

Gambar 7. Anak berlari dan kerjasama dengan timnya

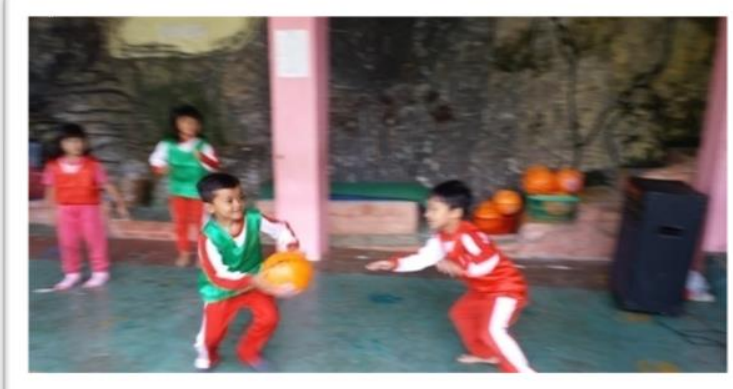

Gambar 9. Anak antusias untuk memasukkan bola basket ke ring lawan 
Penelitian ini juga didukung oleh beberapa hasil penelitian yang menunjukkan bahwa permainan bola basket penting untuk meningkatkan kemampuan motorik kasar anak, kesehatan, kemampuan sosial emosional dan kognitif anak. Salah satunya penelitian oleh Celik \& Johnson (2013) tentang I Need to Move and So Do the Children pada 149 anak prasekolah usia 3-5 tahun yang menyatakan bahwa the physical activity like play basketball, soccer, running, cycling that benefits to physical, social, and cognitive development for children. Hal tersebut juga diperkuat oleh Gustiana (2011) yang mengemukakan bahwa hasil penelitiannya pada permainan modifikasi basket dan sepakbola memberikan hasil cukup efektif dan memberikan kontribusi dalam meningkatkan keterampilan motorik kasar dan kognitif anak.

Temuan lain yang peneliti temukan pada saat pelaksanaan permainan bola basket modifikasi untuk anak usia 5-6 tahun, yaitu anak merasa senang dan sangat antusias dalam mengikuti arahan dari guru dan anak mulai mampu untuk bekerja sama dalam bermain bola basket modifikasi dengan timnya. Pemberian penguatan- penguatan positif atau reinforcement kepada anak akan membuat anak menjadi lebih semangat untuk mau melakukan permainan bola basket, sehingga ketika anak gagal dalam bermain, anak mau mengulang kembali dan berhasil melakukannya dengan baik. Selain itu, melalui permainan bola basket yang telah dimodifikasi ini dapat mengembangkan beberapa kecerdasan, antara lain: 1) kecerdasan kinestetik (anak mampu untuk menguasai tugas gerak dasar dengan baik dan terlatih dalam mengendalikan gerak tubuhnya), 2) kecerdasan interpersonal (melatih anak untuk memahami motivasi dan keperibadian temannya dan adaptasi dengan timnya), 3) kecerdasan visual spasial (saat bermain, anak dilatih untuk bisa memahami kondisi lapangan dan posisi setiap anak dalam formasi, dibutuhkan untuk kemampuan menganalisa ketepatan melempar bola ke ring), 4) kecerdasan logikal matematik (anak dilatih untuk memahami strategi bermain dalam menyerang, bertahan dan memasukkan bola). Dokumentasi pelaksanaan permainan bola basket modifikasi untuk meningkatkan kemampuan motorik kasar anak usia 5-6 tahun dapat dilihat pada gambar 2-9.

Berdasarkan hal tersebut, permainan bola basket modifikasi dapat dijadikan salah satu strategi pembelajaran jasmani untuk mengembangkan kemampuan motorik kasar, memberikan peluang anak untuk bergerak lebih aktif, mengoptimalkan kemampuan gerakgerak dasar (fundamental skills), memberikan manfaat kesehatan bagi diri anak dan dapat mengembangkan kecerdasan anak. Selain itu, bermain bola basket dapat memberikan pengalaman yang menyenangkan bagi anak. Bagi peneliti selanjutnya yang tertarik pada penelitian yang sama, dapat melakukan penelitian di tempat yang berbeda, baik dari sisi sarana dan prasarana, kultur pembelajaran maupun letak geografis yang relatif lebih jauh dari lokasi penelitian sebelumnya dan dapat melakukan penelitian pada aspek perkembangan anak yang lain, misalnya sosial emosional. Hal ini dapat dijadikan pembanding, apakah hasil penelitian yang dihasilkan nanti memiliki kesamaan atau ada perbedaan. Pada akhirnya nanti jika semakin banyak hasil penelitian yang sama, maka kesimpulan penelitian ini dapat melengkapi penelitian yang akan datang untuk menarik penelitian yang lebih umum.

\section{SIMPULAN}

Terdapat peningkatan kemampuan motorik kasar pada anak usia 5-6 tahun dengan pemberian perlakuan permainan bola basket modifikasi. Pada kelompok eksperimen anak lebih unggul dalam menguasai tugas gerak dalam hal koordinasi, keseimbangan, kekuatan dan kelentukan pada keterampilan menangkap, melempar, mendribble, dan memasukkan bola ke ring basket dibandingkan dengan kelompok kontrol. Harapan peneliti, guru dapat lebih kreatif mengembangkan strategi pembelajaran melalui permainan fisik yang dimodifikasi sesuai dengan kebutuhan dan tingkat perkembangan anak sehingga kemampuan motorik kasar anak dapat berkembang secara optimal. 


\section{UCAPAN TERIMA KASIH}

Penulis secara langsung mengucapkan terimakasih kepada semua pihak yang telah membantu dalam kegiatan penelitian ini. Secara khusus penulis mengucapkan terimakasih kepada Ketua Ikatan Guru Raudlatul Athfal (IGRA) Kabupaten Malang, Jawa Timur yang telah banyak membantu dalam proses pelaksanaan penelitian.

\section{DAFTAR PUSTAKA}

Astutik, Fera Setia Puji; Fitri, R. (2019). Pengaruh Permainan "Lola Kena" Terhadap Kemampuan Motorik Kasar Anak Usia 5-6 Tahun Di TK Aisyiyah Bustanul Athfal 25 Wage Sidoarjo. PAUD Teratai, 8(2), 1-6. https://jurnalmahasiswa.unesa.ac.id/index.php/paud-teratai/article/view/29566

Aye, T., Oo, K. S., Khin, M. T., Kuramoto-Ahuja, T., \& Maruyama, H. (2017). Gross motor skill development of 5-year-old Kindergarten children in Myanmar. Journal of Physical Therapy Science, 29(10), 1772-1778. https:/ / doi.org/10.1589/jpts.29.1772

Breslin, G., Murphy, M., McKee, D., Delaney, B., \& Dempster, M. (2012). The effect of teachers trained in a fundamental movement skills programme on children's self-perceptions and motor competence. European Physical Education Review, 18(1), 114-126. https:/ / doi.org/10.1177/1356336X11430657

Fikriyanti, M. (2013). Perkembangan Anak Usia Emas (Golden Age). Laras Media Prima.

Gallahue, D. L. (2006). Understanding Motor Development, Sixth Edition (sixth edit). Mc. Graw Hill.

Gustiana, A. D. (2011). Pengaruh Permainan Modifikasi terhadap Kemampuan Motorik Kasar dan Kognitif Anak Usia Dini. Jurnal Penelitian Pendidikan, Edisi Khus(2), 154-163.

Husdarta, H. J. . (2010). Belajar dan Pembelajaran Pendidikan Jasmani dan Kesehatan. Alfabeta.

Lesmana Melvi, A. (2016). Upaya Meningkatkan Kemampuan Fisik Motorik Kasar Anak melalui. Fajar Pekanbaru, 2(2), 1-11.

Mahmud, B. (2019). Urgensi stimulasi kemampuan motorik kasar pada anak usia dini. DIDAKTIKA : Jurnal Kependidikan, 12(1), 76-87. https:// doi.org/10.30863/didaktika.v12i1.177

Marshall, C. (2017). Montessori education: a review of the evidence base. Npj Science of Learning, 2(1), 1-9. https:/ / doi.org/10.1038/s41539-017-0012-7

Morrison, G. S. (2012). Dasar-Dasar Pendidikan Anak Usia Dini (PAUD) Edisi kelima. PT.Indeks.

Musfiroh, T. (2014). Pengembangan Kecerdasan Majemuk. Hakikat Kecerdasan Majemuk (Multiple Intelegences), 60, 1-60. http:/ / repository.ut.ac.id/4713/2/PAUD4404-TM.pdf

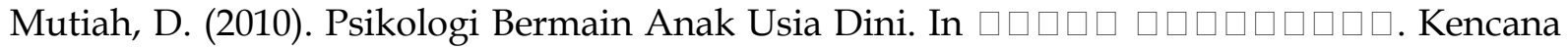
Prenada Media Group.

Pang, A. W. Y., \& Fong, D. T. P. (2009). Fundamental motor skill proficiency of Hong Kong children aged 6-9 Years. Research in Sports Medicine, 17(3), 125-144. https:// doi.org/10.1080/15438620902897516

Papalia. (2009). Perkembangan Manusia Edisi Kesepuluh. salemba Humanika.

Payne, V. Gregory \& Isaacs, L. D. (2012). Human Motor Development: A Lifespan Approach. McGraw-Hill.

Pradaya, B., Admojo, I. R. W., \& Dewi, N. K. (2020). Peningkatan kemampuan motorik kasar melalui permainan modifikasi bola basket pada anak usia 5-6 tahun. Kumara Cendekia, 8(1), 56. https://doi.org/10.20961/kc.v8i1.32572

Ramdani, L. A., \& Azizah, N. (2019). Permainan Outbound untuk Perkembangan Motorik Kasar Anak Usia Dini. Jurnal Obsesi: Jurnal Pendidikan Anak Usia Dini, 4(1), 494. https:// doi.org/10.31004/obsesi.v4i1.407

Rizkiyah, L., Hendrawijaya, A. T., \& Himmah, I. F. (2018). Perkembangan Motorik Kasar Anak Usia 3-4 Tahun Dengan Keterampilan Gerak Dasar Di KB Gita Nusa Kabupaten Jember. Learning Community: Jurnal Pendidikan Luar Sekolah, 2(2), 14-16.

Sevimli-Celik, S., \& Johnson, J. E. (2013). "I need to move and so do the children." International 
DOI: 10.31004/obsesi.v6i1.1182

Education Studies, 6(5), 1-10. https:/ / doi.org/10.5539/ies.v6n5p1

Sitepu, I. D. (2018). Manfaat Permainan Bola Basket Untuk Anak Usia Dini. JURNAL PRESTASI, 2(3), 27. https:// doi.org/10.24114/jp.v2i3.10129

Sugiyono. (2013). Metode Penelitian Pendidikan Pendekatan Kuantitaif, Kualitatif, dan R\&D. In Metode Penelitian Pendidikan Pendekatan Kuantitaif, Kualitatif, dan RED (pp. 85, 221, 273). CV. Alfabeta.

Theobald, M., Danby, S., Einarsdóttir, J., Bourne, J., Jones, D., Ross, S., Knaggs, H., \& CarterJones, C. (2015). Children's perspectives of play and learning for educational practice. Education Sciences, 5(4), 345-362. https://doi.org/10.3390/educsci5040345

Vameghi, R., Shams, A., \& Dehkordi, P. S. (2012). The effect of age, sex and obesity on fundamental motor skills among 4 to 6 years-old children. Pakistan Journal of Medical Sciences, 29(2), 586-590. https:/ / doi.org/10.12669/pjms.292.3069

W.Santrock, J. (2015). Perkembangan anak (W. Hardani (ed.)).

Wiyani, N. A. (2013). Bina Karakter Anak Usia Dini. Yogyakarta. In Ar-Ruzz Media. Ar Ruzz Media.

Wiyani, Novan Ardy. (2014). Psikologi Perkembangan Anak Usia Dini, Panduan bagi Orang Tua dan Pendidik PAUD dalam Memahami serta Mendidik Anak Usia Dini. Gava Media.

Yus, A. (2011). Model Pendidikan Anak Usia Dini (p. 114). Kencana Prenadamedia Grup.

Zirawaga, V., Olusanya, A., \& Maduki, T. (2017). Gaming in education: Using games a support tool to teach History. Journal of Education and Practice, 8(15), 55-64. https://files.eric.ed.gov/fulltext/EJ1143830.pdf 